Naško Križnar

ZRC SAZU
DOI: https://doi.org/10.18485/slovenika.2018.4.1.7 UDK: 791.633-051:929 Zupanc D.

Strokovni članek

Inštitut za slovensko narodopisje

Ljubljana, Slovenija

nasko@zrc-sazu.si

\title{
Filmski mostovi Dragomirja Zupanca med Srbijo in Slovenijo
}

\section{Življenje in delo}

Filmski režiser Dragomir Zupanc je bil rojen 15.1.1946 v Ljubljani. Osnovno šolo in gimnazijo je dokončal v Beogradu. Na njegove kasnejše povezave s Slovenijo je vplivalo večkratno bivanje pri sorodnikih v času otroštva. ${ }^{1}$ Diplomiral je iz filmske režije na Fakulteti dramskih umetnosti, v razredu profesorjev Aleksandra Petrovića in Save Mrmaka leta 1971. Naslov njegove diplomske naloge je enak naslovu TV oddaje, ki jo je naredil kot del diplomske obveznosti: »Igraj gorostase na moju nežnu muziku« po motivih slike Paula Kleeja, s sodelovanjem baletne skupine Mire Sanjine. Oddaja je bila zmontirana iz filmskih posnetkov in posnetkov baletne skupine v studiu. S tem delom je Zupanc naznačil svojo usmeritev $\vee$ pretežno televizijsko ustvarjanje.

Hkrati s končevanjem univerzitetnega študija je pisal za časopis Student, bil je član uredništva časopisov 'F' in Vidici, objavljal je v Sineastu (Sarajevo), Ekranu (Ljubljana) ter v beograjski Politiki, NIN-u in Danasu. Je eden od ustanoviteljev časopisa Filmograf (1976).

Iz slovenščine je prevajal poezijo T. Šalamuna in I. Svetine, prozo M. Švabiča in radio drame P. Lužana. Za časopisa Student in Vidici je prirejal besedila iz ljubljanske Mladine in Tribune.

Od leta 1971 do 1985 je deloval kot svobodni umetnik. Pogodbeno je delal za Radio televizijo Srbija (RTS), pisal za omenjene časopise in bil od leta 1975 do 1977 honorarno urednik filmskega programa v Študentskem kulturnem centru v Beogradu. Od leta 1972 je član Udruženja filmskih umetnika Srbije (UFUS), kjer je bil več let vodja strokovne tribune in predsednik sekcije dokumentarnega filma. Od leta 1985

\footnotetext{
${ }^{1}$ Glej: Slovenija v mojem srcu. Moji spomini - Dragomir Zupanc. Bilten Društva Slovencev v Beogradu - Društva Sava, junij 2018, str. 18-19.
} 
do 1990 pa je bil odgovorni urednik zabavnega programa RTV Črne gore. Preden se je leta 1996 redno zaposlil na RTS, je spet delal kot samostojni umetnik, honorarno tudi za RTS, TV Politiko in Studio B. Od leta 1996 do upokojitve leta 2010 je bil vodja skupine režiserjev na RTS. Živi in dela v Beogradu. Od leta 2015 je član Akademije za filmsko umetnost in znanost Srbije.

Zupanc je od leta 2005 aktivni član Društva Slovencev v Beogradu - Društva Sava, kjer je predsednik odbora za kulturo. Je tudi član Nacionalnega sveta slovenske manjšine $v$ Srbiji.

Leta 2015 je pripravil Prve dneve slovenskega filma v Beogradu, v okviru dejavnosti Društva Sava. Ta odmevna prireditev je bila v dvorani Jugoslovanske kinoteke leta 2018 že četrta po vrsti.

Zupančev opus del za televizijo je izredno obširen. Na tem mestu in $\checkmark$ tem intervjuju se bomo omejili na specifičen del njegovega filmskega ustvarjanja, ki je povezan z njegovim delom v Društvu Slovencev v Beogradu - Društvu Sava, in z njegovimi deli, posnetimi v Sloveniji za RTS, tudi v sodelovanju z drugimi producenti. Ta del njegovega opusa šteje 19 enot od leta 1975 do leta 2017.

Zupanc je za svoje filme prejel več nagrad, zlasti potem, ko je začel ustvarjati serijo portretov znanih jugoslovanskih cineastov (Žilnik, Makavejev, Godina, Vučićević) in filmov o drugih srbskih umetnikih (Kiš). Čeprav ti filmi ne spadajo v okvir naše obravnave, je vseeno primerno, če navedemo nagrade, ki jih je prejel zanje. Tako je na Festivalu dokumentarnega in kratkometražnega igranega filma v Beogradu 2005 prejel nagradi za TV filma »Prispevki za zgodovino YU filma in politpornografijo - Želimir Žilnik« (zlata medalja za režijo in Plaketo UFUS Jovan Aćin), na Televizijskem festivalu v Baru 2004 za film »Svetibor« (zlatna maslina $v$ kategoriji turističnega filma) in za film »Prispevki za zgodovino YU filma in politpornografijo - Želimir Žilnik« na Televizijskem festivalu v Baru 2005 (srebrna maslina v kategoriji dokumentarnega filma).

\section{Izbrani filmi, ki so predmet intervjuja}

Za oddaje iz serije Dvogled pri RTS je režiral več filmskih prispevkov o Sloveniji. Dvogled je bila redna oddaja za otroke. Vodil jo je urednik Dragan Babić, tesen Zupančev sodelavec v sedemdesetih letih. Vsako oddajo so sestavljale reportaže iz vse Jugoslavije o posebnostih izbranih krajev in ljudi, s sproščenim Babićevim vodenjem in gosti. Med oddajami so bile nekatere posvečene tudi eni sami temi, npr. »Slovenske lipe« ali »Lipica«. V obravnavanem opusu je evidentiranih 7 oddaj Dvogled iz Slovenije v obdobju 1975/76, ki jih je režiral Zupanc. Prispevki za oddaje so bili posneti na $16 \mathrm{~mm}$ traku, največkrat $v$ črno beli tehniki. 
Na podlagi poznavanja etnoloških posebnosti v zahodni Sloveniji je nato Zupanc leta 1979 za RTS posnel pravi etnografski TV dokumentarec »Ta grdi«, o raziskovanju znamenitega ljudskega pustovanja v Drežnici pri Kobaridu. Ekipa je skupaj s kustosom Goriškega muzeja v Novi Gorici spremljala dogajanje na terenu in nato še analizo ter interpretacijo rezultatov terenskega dela. Ta film ni bil posnet za redakcijo otroškega programa, tako kot oddaje Dvogled, temveč za redakcijo znanstvenega programa RTS. Urednik filma je bil Ilja Slani, ki je tudi kasneje pokazal veliko zanimanja za etnološke teme.

Zupanc je v začetku 80. let režiral oddaje za serijo Nova umetnost, v kulturni redakciji RTS z legendarno odgovorno urednico Zoro Korać. Posebnost prve oddaje iz serije Nova umetnost, imenovana tudi »Umetnost dvajsetih let«, pod uredništvom Dunje Blažević je v tem, da so vanjo vključeni posnetki Avgusta Černigoja in Eduarda Stepančiča v Trstu. Konstruktivizem in Zenitizem sta bila takrat tudi osrednji temi razstave v beograjskem Narodnem muzeju.

Leta 1983 sta z Blaževićevo posnela »Umetnost sedemdesetih let«. Pred tem sta se že ukvarjala s skupino konceptualnih umetnikov v galeriji Študentskega kulturnega centra, ki so skupaj z Lucom Beckerom posneli, zdaj že antologijski, film »Kino beleške« (1976). Kadre iz tega filma sta vkomponirala $v$ oddajo in na ta način predstavila takrat še anonimno skupino: Ero Milivojevića, Zorana Popovića, Nešo Paripovića, Rašo Todosijevića in Marino Abramović. Potem sta obiskala Zagreb in posnela perfomanse Gorana Trbuljaka, Brace Dimitrijevića, Sanje Iveković, Mladena Stilinovića, Jagode Kaloper in Toma Gotovca.

Zupanc je za to oddajo organiziral snemanje ljubljanske alternative in s pomočjo arhiva Naška Križnarja ter posnetkov iz oddaje Dvogled naredil zgodbo o skupini OHO in o zakoncih Nuši in Sreču Draganu. Obe oddaji sta magazinskega značaja, s poudarkom na strokovnem komentarju posameznih tem.

Film »Okvir za nekaj slik« (2006) spada v serijo portretov jugoslovanskih cineastov, ki jih je Zupanc režiral za RTS, portret režiserja Karpa Godine v omenjenem filmu pa z RTV Slovenija kot koproducentom. Godina je slovenski režiser in filmski snemalec, ki je po uspehih z amaterskimi filmi v času študija režije na Akademiji za gledališče, film in televizijo v Ljubljani vzbudil pozornost producentov in kritike kot direktor fotografije v Žilnikovem filmu »Zgodnja dela« (1969). Godina je s tem vstopil v srbsko kinematografijo, kar mu je kasneje odprlo več možnosti tudi za delo v Sloveniji. Zlasti pa je pomembno, da je Žilnikova matična produkcijska hiša Neoplanta film iz Novega Sada po uspešnem sodelovanju z Godino odprla vrata tudi drugemu Slovencu, N. Križnarju za njegov prvi kratki film.

Portret oz. življenjepis je tudi tema Zupančevega filma o Eduardu Stepančiču. Ta avtor je bil član Tržaške konstruktivistične skupine (Gruppo costruttivista di Trieste) Avgusta Černigoja in sodelavec edinstvene 
avantgardistične revije Tank (1927). Skupaj s Černigojem je razstavljal na znameniti razstavi v Obrtniškem domu v Trstu v dvajsetih letih. Kot avantgardist/konstruktivist je bil Stepančič dolgo časa neopazen $\mathrm{s}$ strani raziskovalcev umetnosti. Tudi v Beogradu, kjer je živel od leta 1931, je dolgo trajalo, da se je razkril kot Černigojev učenec in še vedno aktivni likovnik. Po 2. svet. vojni je sicer razstavljal na društvenih razstavah v Beogradu, toda šele pregledna razstava v Ljubljani leta 2006 je Stepančiča v celoti odkrila tako slovenski kot srbski javnosti in ga postavila na pravo mesto $v$ zgodovini likovne umetnosti.

Filma »Okvir za nekaj slik« (2006) in »Eduard Stepančič« (2006) sta potrdila Zupanca kot odličnega filmskega portretista. To pa je veščina, ki jo je Zupanc v celoti razvil kasneje tudi pri filmih o Slovencih $\checkmark$ Beogradu. Zupanc zna $v$ filmu še posebej občuteno oblikovati problematiko umetnikov in umetnosti. Ni naključje, da je v obravnavanem opusu kar šest del posvečenih umetnikom in njihovim delom: ob zgoraj omenjenih dveh še oddaji iz serije Nova umetnost, »Umetnost dvajsetih« in »Umetnost sedemdesetih« $(1982,1983)$, »Trije akordi« (2014) in »Davorin Jenko« (2014).

Film »Sava v Beogradu« (2011) je bil posnet ob desetletnici Društva Sava. V njem nastopa veliko beograjskih Slovenk in Slovencev, zaslužnih za ustanovitev in delovanje društva, veliko več kot v drugih Zupančevih filmih. Zato je ta film nekakšen skupinski portret društva in njegovih ciljev, ki bi jih na kratko lahko povzeli kot: ohranjanje nacionalne identitete, zlasti jezika, in sodelovanje z večinskim narodom. $\checkmark$ ta namen je društvo razvilo niz aktivnosti, od dopolnilnega pouka slovenščine do petja, plesa, izdajanja publikacij, prirejanja kulturnih dogodkov in obiskovanja Slovenije.

Temu filmu je sledila serija petih filmskih portretov Slovenk in Slovencev, ki so s svojim delom pustili močno sled v Srbiji, ne samo med slovensko manjšino. Življenjske zgodbe v teh Zupančevih filmih pričajo o različnih stopnjah integracije slovenske manjšine $v$ srbsko družbo pred drugo svetovno vojno in po njej. Čeprav so številni med njimi ohranili stike s svojimi sorodniki v Sloveniji, ne skrivajo, da jih je prizadel razpad Jugoslavije. V filmskem portretu Ane Pečnik alias Mirjane Simić vidimo, da ona živi dobesedno v obeh svetovih. Poletje preživi v svoji domači hiši v Sloveniji, zimo pa v Beogradu.

Pri omenjenih Zupančevih filmih je zanimivo njihovo produkcijsko ozadje. Kot producent ali koproducent sta $v$ filmih vedno navedena Društvo Sava ali Nacionalni svet slovenske manjšine v Republiki Srbiji, razen pri filmu »Trije akordi«, ki je nastal v produkciji RTS, vendar tudi s sodelovanjem Društva Sava. Ob omenjenih producentih so pri produkciji nekaterih filmov sodelovali še Ministrstvo za kulturo in informiranje Republike Srbije in Ministrstvo za izobraževanje, znanost, kulturo in šport Republike Slovenije, Urad vlade Republike Slovenije za Slovence v zamejstvu in po svetu ter Rokodelski center Ribnica. Razen Zupanca, 
ki je filme režiral, pa tudi pisal ali sodeloval pri pisanju scenarijev, so v odjavnih napisih nekaterih filmov navedeni številni člani Društva Sava, tako npr. Maja Đukanović, Anica Sabo, Marija Vauda, Biljana MilenkovićVuković, Darja Kovrlja in Saša Verbič.

V Zupančevem opusu za Društvo Sava so od leta 2011 do 2017 v zgodovino društva s filmskimi portreti vpisane naslednje žive in preminule osebnosti slovenske manjšine: Eduard Stepančič, Ana Pečnik alias Mirjana Simić, Edo Cvar, Ivan Debeljak, Zlatan in Marija Vauda, Nuša in Rene Gerden ter Davorin Jenko iz daljne preteklosti. Še več osebnosti nastopa v že omenjenem filmu »Sava v Beogradu« (2011), ki je pregled zgodovine društva skozi pripoved številnih aktivnih članic in članov.

Živi in pokojni protagonisti, pripadniki slovenske manjšine v Srbiji, so omogočili nastanek naslednjih filmov: "Sava v Beogradu« (2011), »Ena slovensko-srbska zgodba« (2011), »Sita in rešeta mojstra Debeljaka« (2012), »Trije akordi« (2014), »Davorin Jenko« (2014) in »Življenje in spomin « (2017). Podatke o teh in drugih obravnavanih filmih najdete v Izbrani filmografiji ob koncu intervjuja z Dragomirjem Zupancem.

Značilnost omenjenih šestih filmov je, da je snemanje potekalo tako v Srbiji kot v Sloveniji, na lokacijah, ki so jih narekovale življenjske zgodbe protagonistk in protagonistov. In pri teh »navzkrižnih« filmih je Zupanc na preprost in zanimiv način prikazal dvojezičnost akterjev. V Srbiji govorijo srbsko, v Sloveniji pa slovensko, navadno s pridihom narečja svojih domačih krajev.

\section{Namesto zaključka}

Zupančevi filmi so vsi narejeni za javno predvajanje. Seveda je to upravičeno in pričakovano za televizijski del obravnavanega opusa, vendar je avtor težil k podobnemu načinu tudi v filmih za Društvo Sava. Tudi ti filmi vsebujejo standardne komunikacijske sestavine dokumentarnega TV filma: komentar, napise, glasbeno spremljavo, korektno montažo za ustvarjanje kontinuitete in skrajševanje realnega časa ter seveda tudi sinhroni ton dialogov in ambienta, kar ni bilo lahko doseči v skromnih produkcijskih pogojih zadnjih filmov. Zupanc ima rad dinamično filmsko pripoved. Mestoma si izjave protagonistov, pripovedi in lokacije celo prehitro sledijo, kot npr. v filmih »Življenje in spomin« in »Ena slovensko-srbska zgodba«, kjer se gledalci kar težko znajdemo $\checkmark$ zapletenih sorodstvenih odnosih, podanih $v$ hitrih montažnih rezih. Morda bi tematika teh filmov zaslužila bolj komorno filmsko formo. Vendar so Zupančevi filmi ravno zaradi jedrnate filmske govorice dosegli dokaj široko občinstvo. Niso bili predvajani samo v društvu, temveč tudi $\vee$ javnem televizijskem omrežju $\vee$ Srbiji in na nekaterih filmskih festivalih v Srbiji in v Sloveniji.

"Sava v Beogradu« in "Sita in rešeta mojstra Debeljaka« sta bila predvajana tudi na mednarodnih Dnevih etnografskega filma $v$ Ljublja- 
ni. S tem je bila legitimirana ali vsaj tematizirana etnološka komponenta Zupančevega filmskega ustvarjanja. Oba omenjena filma, pa tudi drugi iz izbrane filmografije so polni podatkov o usodah in življenjskih načinih pripadnikov manjšine. Manjšinska problematika je eminentna tema etnoloških in antropoloških raziskav. $\vee$ Zupančevih filmih še posebej izstopa sestavina t. i. trans nacionalnosti, ki je danes tako značilna in pomembna za preučevanje manjšinske in migrantske problematike $v$ Evropi. Ta sestavina nakazuje polemiko o tem, ali je integracija izseljencev in migrantov, kot smo jo pojmovali doslej, edina mogoča oblika sobivanja $v$ današnjem globaliziranem svetu. Zato na obravnavane Zupančeve filme lahko gledamo tudi kot na »tekste«, relevantne za preučevanje kulture, tem bolj, ker se tičejo nam bližnjih okolij, slovenskega in srbskega. Malo manj izrazito bi jih lahko označili kot etnografske filme na ravni slogovnega statusa. Vsi so namreč narejeni $\checkmark$ modusu standardnega TV dokumentarca in ne $v$ modusu sodobnega obzervacijskega etnografskega filma, vendar v Zupančevem primeru to »pomanjkljivost« značaja njegovih filmov odtehta posvečenost predanemu dokumentiranju manjšinskih osebnosti in njihovih pestrih (beri: dramatičnih) življenjskih zgodb. Številni so s svojimi pripovedmi dobili v filmih prvoosebni (beri: privilegiran) glas. Zaradi tega bodo

lahko s svojimi prikazanimi kulturnimi vzorci vedno pomemben dokument tako za slovensko kot za srbsko družboslovje in humanistiko.

Za obravnavani del Zupančevega opusa so značilni raznoliki dokumentaristični pristopi. Oddaja Dvogled je npr. bolj reportažnega in magazinskega značaja. D. Babić uvede temo, sledijo izjave protagonistov na terenu, vmes je nekaj detajlov in panoram, ki gledalcu približajo tematiko. Večini enot te serije se pozna, da so posnete in zmontirane na hitro, zelo reportažno. Veliko je improvizacij D. Babiča. Podobnega značaja sta tudi oddaji iz serije Nova umetnost. Iz poznih sedemdesetih let je najbolj analitičen in sam v sebi zaključen film »Ta grdi«, ker sledi strokovni raziskavi in analizi, kolikor je to mogoče $v$ formi standardnega TV dokumentarca. Za kasnejše filme, posnete za Društvo Sava v obdobju 2011-2017, pa je značilna temeljitost v prikazih posameznih osebnosti iz manjšinskega sveta, podkrepljenih s številnimi dokumenti o časih, krajih in ljudeh, ki ustvarjajo zgodovinsko in kulturno ozadje podanega dogajanja.

Posebno kakovost najdemo v dobro pripravljenih TV dokumentarcih o znanih kulturnikih. To so filmi »Eduard Stepančič« (o skoraj pozabljenem konstruktivistu Černigojevega kroga), »Trije akordi« (slikarka Marija Vauda o svojem očetu glasbeniku) in »Davorin Jenko« (slovenski skladatelj, avtor aktualne srbske himne). Slednji je poseben $v$ tem, da je Zupanc uvedel kostumiranega komentatorja, ki nas vodi skozi film.

Ustvarjalno sodelovanje Društva Sava pri produkciji filmov o usodah slovenskih ljudi v Srbiji je gotovo povečalo zavedanje pripadnikov manjšine, da je filmsko dokumentiranje izjemno pomembno za ohra- 
njanje nacionalne identitete manjšine, ne samo kot oblika arhiviranja podatkov o ljudeh in življenju, temveč tudi kot specifična kulturna dejavnost manjšine. Morda se bo $v$ društvu na tej podlagi razvilo sistematično video dokumentiranje društvenih aktivnosti kot redna oblika društvene dejavnosti. Nekaj posnetkov že lahko vidimo na spletni strani Društva Sava. Sčasoma bo nastal dragocen arhiv vizualne dokumentacije, ki bo služil za preučevanje dejavnosti manjšine v Srbiji, ali pa za uporabo v zahtevnejših dokumentarnih filmih o slovenski manjšini, kot je npr. Zupanc to pokazal v filmu »Sava v Beogradu«.

O Zupancu in njegovem delu najdemo precej podatkov na različnih internetnih straneh. Večinoma gre za suhoparne in ponavljajoče se podatke iz delovnega življenjepisa, pretežno o njegovem delu za televizijo. O Zupančevi mladosti, povezani s Slovenijo, veliko izvemo iz njegovega zapisa v Biltenu Društva Sava, ${ }^{2}$ o njegovi bolečini po razpadu Jugoslavije pa $v$ reportaži $\vee$ Nedeljskem. ${ }^{3} Z$ brskanjem po spletu naletimo tudi na Dneve slovenskega filma v Beogradu, ki jih pripravlja Zupanc skupaj s sodelavci iz Društva Sava, redno od leta 2015. Zato v zadnjih letih sistematično spremlja dogajanje v slovenski kinematografiji in nekatere filme za program Dnevov izbere že na vsakoletnem portoroškem Festivalu slovenskega filma. V ustreznih oddajah RTS nato s kratkimi opisi vsebine programa Dnevov slovenskega filma poroča srbskim televizijskim gledalcem. Enega takih uvodov najdemo na spletu. ${ }^{4} \mathrm{Na}$ kratko je o Zupančevih delih za Društvo Sava pisala Maja Đukanović v uvodu k predvajanju filma »Življenje in spomin«. ${ }^{5}$ Poudarja, da je to film, ki so ga ustvarili izključno beograjski Slovenci, člani Društva Sava. Nato pa našteje še druge filme, ki jih je Zupanc režiral na temo Slovencev v Srbiji.

Del Zupančevega filmskega opusa, ki zadeva življenjske zgodbe Slovencev $\vee$ Srbiji, zlasti $v$ Beogradu, je fascinanten. Dvomim, da je še kje na svetu manjšinska organizacija s tako izvirnim načinom refleksije o svojem »žitju in bitju«, kot je to primer med slovensko manjšino v Srbiji in še posebej v Društvu Slovencev v Beogradu. Od leta 2011 do 2017 je nastalo šest filmskih naslovov s produkcijskim in avtorskim sodelovanjem članov Društva Sava!

Zupančevi filmi o Slovencih v Beogradu so, ob tem da so dobra komunikacija med manjšino in večinskim narodom v Srbiji, izredno dra-

\footnotetext{
2 Glej: »Slovenija v mojem srcu. Moji spomini - Dragomir Zupanc«. Bilten Društva Slovencev v Beogradu - Društva Sava, junij 2018, str. 18-19.

${ }^{3}$ Glej: Mateja A. Hrastar, »Še vedno čutim bolečino razpada države«. Nedeljski (Ljubljana), 22.11.2017, str. 7.

${ }^{4}$ Spletni vir: https://www.youtube.com/watch?v=JAQTWJGdz3U

${ }^{5}$ Spletni vir: SLOKULT.INFO, februar 2018: ttps://slokult.info/aktuelno/2018/2/8/filmdragomirja-zupanca-ivljenje-in-spomini-nua-in-ren-gerden
} 
gocena informacija tudi za ljudi v Sloveniji. Omogočajo nam, da zgodovina in posebnosti manjšine skozi usode vidnih posameznikov zaživijo pred našimi očmi na veliko bolj plastičen način, kot bi to dosegli le $\mathrm{s}$ pisnimi, fotografskimi in drugimi pričevanji.

\section{Pogovor z Dragomirjem Zupancem}

Razgovor je vodil Naško Križnar.

Kaj je zate pomembno v povezavah s Slovenijo, kar ti je tudi kasneje $v$ Srbiji omogočilo, da si ohranjal stike s slovenskim prostorom, tako osebno kot profesionalno?

Moje otroštvo je povezano z nekoliko mesti in kraji širom Slovenije. Dobro se spominjam hiše $v$ železničarski koloniji, ko sta ded in babica živela v Ljubljani. Tetka in ujec sta me vozila na biciklu in spominjam se rampe na današnjem Razstavišču. Kasneje, ko se je ded kot postajni načelnik selil na nova delovna mesta, sva z bratom počitnice preživljala na peronih in v postajnih zgradbah v Tržiču na Gorenjskem ter potem v Rušah na dravski železnici. Tu sva spoznavala slovensko mentaliteto in življenjski slog, začenši od vrta in babičinih kuharskih veščin, preko grabljenja sena in nabiranja jabolk, do obiska Pohorja in nabiranja borovnic. A moj najvažnejši dogodek, tudi v življenjskem smislu, je vpis na Fakulteto za arhitekturo v Ljubljani leta 1964. Za beograjskega maturanta je bilo to odločilno leto za nadaljnji intelektualni in družbeni razvoj. Ta šola je bila pod Plečnikovim vplivom, nedaleč od njegovega ateljeja, s profesorji iz njegovega obdobja, pa tudi s tedanjimi avtoritetami na področju arhitekture: Ravnikarjem, Mušičem, Vidmarjem. Ljubljanski portali in fasade so se mi vtisnili v podzavest. To so bila prelomna leta, moderna je triumfirala, gradili so se Trg republike, Mercator, Cankarjev dom, Hala Tivoli, Kino Šiška. Ravnikar je gradil na Trgu republike, Mušič na Bavarskem dvoru. Ljubljano sta si razdelila kot nekdaj Plečnik in Fabiani. Od takrat gledam na rojstno mesto z drugimi očmi. Estetika urbanega je postala zame najvažnejši pogoj za življenje in bivanje v nekem mestu.

Sodeloval si s številnimi časopisi, ki so se $v$ tvojih mladih letih ukvarjali s filmsko kulturo v Beogradu. Ali lahko poveš nekaj o svojih začetkih s filmsko publicistiko?

»F« se je imenoval časopis Filmske omladine Srbije, v katerem sem objavil prvi članek, in sicer portret Milene Dravić. Izšle so samo tri številke, po ena na leto, od 1966 do 1968.

Ta izkušnja mi je pomagala pri sodelovanju v ljubljanskem Ekranu, sarajevskem Sineastu in, skupaj z Zečevićem, pri ustanovitvi časopisov Filmoforum (1975) in Filmograf (1976). Filmforum je bil poligon za 
razne oblike obračuna z nazadnjaško in na ideološki ravni osnovano teorijo in filmsko prakso.

V prenovljeno redakcijo Vidikov so leta 1971 poleg mene vstopili še Stojanović, Ristić, Ilić in Zečević. Tu smo nadaljevali s propagiranjem ideje in prakse iz prepovedanih številk Studenta, časopisa, ki je leta 1968 objavil t. i. "Lipanjska gibanja«. Ukvarjali smo se s sodobnimi teorijami, umetniškimi praksami, med drugimi z gledališko predstavo in skupino Pupilija Ferkeverk v Ljubljani, prevajali tekste iz ljubljanskih Problemov, predstavljala aktivnosti skupine OHO. Tako sem objavil tudi tvoj tekst, ki sem ga prevajal skupaj s pesmijo Tomaža Šalamuna in prozo Marka Švabiča. Na žalost je oblast po izidu številke, posvečene Nacionalsocializmu, prepovedala in dala sežgati Vidike. Tudi redakcijo so razpustili.

Filmograf je bil medtem bolj strokoven časopis, s poudarkom na avtorski praksi in sodobni kinematografiji. Ko se je začela hajka na »črni film«, me je novi glavni urednik Predrag Golubović vrgel iz redakcije. Nisem bil primeren zaradi sodelovanja $v$ gibanjih in stavkah $v$ sedemdesetih in solidariziranja z Makavejevim, Žilnikom, Pavlovićem in profesorjem Petrovićem, nosilci tako imenovanega »črnega filma«.

Zdi se mi, da je za tvoje delo na beograjski televiziji zelo pomembna oddaja Dvogled?

Za televizijo me je »odkril« Raša Popov in mi dal režirati serijo Odprta Univerza v Znanstvenem programu. Spominjam se, da sva za eno od epizod leta 1970 potovala v Ljubljano na Sejem informatike.

Potem sem se približal Otroškemu programu urednika Dragana Babića in začel režirati Dvogled. Potoval sem v Slovenijo zbirat gradivo za scenarije. Pomagali so mi prijatelji iz študentskih časov, predvsem ti, ki si bil takrat kustos etnolog v Goriškem muzeju v Novi Gorici.

Iz tega raziskovanja je v letih 1975/77 nastalo več oddaj o Krasu, Valvazorju, Idriji, Tolminu, dolini Soče. Babić je bil izven serijski erudit in komunikator. Otrokom je razlagal čudeže sveta in je vedel, kako se jim približati in jim vsaditi v glavo življenjske resnice. Prvi je posnel skupino $\mathrm{OHO}$ in ji dal prostor na prvem kanalu TV Beograd že leta 1974. Zaradi tega sva šla večkrat k Marku Pogačniku v Šempas. Najprej sva snemala delovanje prve šempaške »komune«, potem odraščanje Markove hčerke Ajre in vsakdanje življenje $v$ Pogačnikovi družini v Šempasu. Kopije teh oddaj so shranjene tudi v Moderni galeriji v Ljubljani, skupaj z drugimi dokumenti skupine $\mathrm{OHO}$.

\section{Kam te je vodila pot po oddaji Dvogled?}

Po seriji Dvogled sem v Sloveniji delal dva pomembnejša projekta. Z urednikom Znanstvenega programa Iljom Slanim sva snemala namenske oddaje, zanimive za ta program, z Dunjo Blažević, urednico Kulturnega programa, pa umetnike in dogajanja na kulturnem po- 
dročju. Tako smo za Znanstveni program posneli oblikovalca Oskarja Kogoja v Mirnu pri Gorici in Arheološki oddelek na Filozofski fakulteti $\checkmark$ Ljubljani. Drugi projekt pa je snemanje ljudskega pustovanja v Drežnici pri Kobaridu z etnologom Naškom Križnarjem. To je film »Ta grdi« iz leta 1979. Delali smo z dvema snemalskima in tonskima ekipama hkrati, na $16 \mathrm{~mm}$ barvni film. Spominjam se, da so bila prizorišča polna divje življenjske energije, ki je nosila »grde«, demonske like, po katerih ima filma naslov. Križnar je bil komentator na prizoriščih, raziskovalec in dokumentarist celodnevnega dogajanja. Mislim, da je bila to krona najinega večletnega poznanstva.

Ali si tudi kot urednik filmskega programa v SKC uveljavljal svoje poznavanje slovenskega filma?

V tistem času, v sedemdesetih letih prejšnjega stoletja, so bili slovenski avtorji redno zastopani v sporedu beograjskih kinematografov kot ostali filmski ustvarjalci tedanje države. Moje poznavanje slovenskega filma pa se je pokazalo na programih filmskih tribun SKC, kjer so sodelovali moji slovenski znanci, zlasti na panelih, posvečenih alternativnemu filmu. Tako ste bili gosti Karpo Godina z Gratiniranimi možgani Pupilije Ferkeverk in ti z Belimi ljudmi. Se razume, da je imel retrospektivo Hladnik, ker sta bila »Ples na dežju« in »Maškarada« zelo dobro sprejeta pri srbski kritiki.

Opiši, prosim, kako se je začelo ustvarjanje filmov v okviru Društva Sava? Kako se je razvila osnovna zamisel za filmsko dokumentiranje dela društva in vidnih pripadnikov manjšine?

Kmalu po mojem vstopu v Društvo Sava leta 2005 smo ugotovili, da so se nekateri člani društva že ukvarjali s filmom in televizijo: Andrej Dimitrijević, takrat profesor montaže in prodekan Fakultete dramskih umetnosti, Breda Čoš, televizijska režiserka, Aleksandar Gruden, gledališki in filmski igralec. Na zamisel za prvi film o Društvu Sava sta prišli Maja Đukanović in Anica Sabo, obe profesorici Univerze v Beogradu in članici Društva Save od samega začetka. Tako je bil film narejen ob 10. obletnici Društva Slovencev v Beogradu - Društva Sava. V filmu sta Maja in Anica tudi nastopali, skupaj z Biljano Milenković - Vuković in Darjo Kovrlja, ki sta tudi obe aktivistki Društva Sava. To je bil šolski primer dokumentarca, kjer je bilo najvažneje zabeležiti aktivnosti članov društva in pomen zbiranja beograjskih Slovencev zaradi ohranjanja posebnosti in običajev, ki so jih prenesli iz rodnih krajev.

Za snemanje izjav sem izbral Caffe vrt Slow nasproti mojega stanovanja v Dubljanski ulici, ki je bil idealen za snemanje pogovorov. $\checkmark$ tem prostoru sem večkrat posnel tudi nekatere kadre za moje TV oddaje, tam sem se vedno počutil varno in sproščeno. Zdaj so ti posnetki zgodovinski; vrt so podrli, gradijo stavbo s šestimi nadstropji, ulici pa so spremenili ime v Nikolaja Hartviga, ruskega konzula, ki ga 
je $v$ Avstro-ogrskem veleposlaništvu zadel infarkt po napovedi vojne Srbiji leta 1914.

Na zamisel za drugi dokumentarec, »Ena slovensko-srbska zgodba«, sem prišel preko soproge Radmile. Delala je kot sodelavka gospe Mirjane Simić, Slovenke iz Bistrice na Sotli. Ona se je pod imenom Ana Pečnik leta 1941 znašla v Smederevski Palanki, kjer je bila profesorica v šoli. Vso vojno je prebila v Srbiji. Človek, s katerim se je poročila, ji je dal novo ime (Mirjana) in priimek. Tako je nastal portret žene z dvema imenoma in dvojnim življenjem: v stanovanju na platoju pri cerkvi Sv. Save v Beogradu in v družinski hiši v Bistrici na Sotli. Dobil sem dovoljenje družine za intervju z devetdesetletno starko. Prosil sem izkušenega televizijskega novinarja Jovana Pavlička, da snema s svojo pol profesionalno kamero. Gospa Mirjana je do podrobnosti pripovedovala, kaj se ji je dogajalo v tistih težkih dneh, in z lahkoto je prešla iz srbščine $v$ slovenščino, ko sem jo to prosil. Potem sem izkoristil bivanje v Pišecah v Sloveniji in na vabilo Simićevih odšel s snemalcem lokalne televizije Vladimirjem Bogovčičem v Bistrico. Tam sva posnela slovenski del zgodbe gospe Pečnik - Simić. Ker sem bil že eno leto upokojenec, je bilo to moje prvo delo brez produkcijske podpore RTS. Pravzaprav je bilo, kot da začenjam vse znova, vse je bilo odvisno od mene in mojih sposobnosti. Pavliček in njegova soproga Vesna sta mi pomagala, da pripeljem projekt do konca, Jovan kot montažer, Vesna kot sodelavka in sogovornica gospe Mirjane - Ane.

Zanima me, kako so na tvoje delo za Društvo Sava v zadnjem obdobju vplivale tvoje izkušnje pri delu za televizijo? Kako se je, skratka, oblikovala tvoja filmska misel $v$ obravnavanem obdobju?

Zame je televizija kompleksna zadeva. Tu se naučiš hitro reagirati na prizorišču, ko delaš neposredne prenose dogajanja, ali pa se, po drugi strani, dolgo pripravljaš na snemanje dogodkov ali oseb, ki jih želiš obravnavati. Film, o katerem smo se učili v šoli in v kinu, postane zgolj podzavestna misel; na realnem prizorišču ti ne pomagata niti Eisenstein niti Godard. Ekipa pričakuje natančne naloge: kam luč, kam kamero, kam mikrofon! Seveda sem bil na začetku zastopnik »cinéma vérité«, kamera iz roke, neposreden vstop na sceno, vpletanje v dogodek, brezkompromisen pristop $\mathrm{k}$ ljudem in provociranje posameznika. Znal sem sredi noči dvigniti ekipo zaradi nekega ciganskega orkestra in ciganke $v$ leseni baraki, ko so v predmestju izvajali pesem Đelem, đelem, znano po filmu mojega profesorja Petrovića, čeprav smo v tem trenutku pravzaprav snemali oddajo za Znanstveni program.

V pristopu k temam, povezanim z aktivisti Društva Sava, sem več pozornosti posvečal možnosti poglobljenega dostopa do sogovornikov in do vsebine. Ivan Debeljak, drugi lik iz ciklusa portretov beograjskih Slovencev, je osebnost s tremi obrazi. Je mojster za izdelavo sit, glasbenik in Slovenec starega kova, čeprav rojeni Beograjčan. On je glavni! 
Zato sem zaprosil za pomoč mojo bivšo hišo RTS in z Vesno Pavliček, urednico serije Predniki in potomci, posnel Cvarovo delavnico in hišo na Crvenom Krstu. Debeljak nam je odprl »prostor«, v katerem je shranjena zgodovina Slovencev, prispelih v glavno mesto države po prvi svetovni vojni: njihovo prilagajanje, ohranjanje tradicij in opravljanje verskih šeg. To je bila vez, ki me je močno povezala z bistvom našega obstoja v novem okolju in kulturi. Harmonika, Ivanov inštrument, se me je posebej dotaknil, ker je moj oče Josip igral in učil harmoniko. A muzika, solistično in zborovsko petje se prepletajo skozi ves film. Slovenci so še kako vplivali na glasbeno življenje v Srbiji! V slovenskem delu filma, v Ribnici, odpiramo drugo stran. Zgodba o suhi robi in legenda o pridobitvi cesarjevega patenta, dovoljenja za opravljanje obrti, nas neposredno uvede v skoraj pet stoletij staro tradicijo ribniškega obrtništva. Debeljak se s pomočjo narečja spremeni v krajana in njegovo občevanje $z$ domačimi mojstri je režirano in posneto $v$ čistem dokumentarističnem slogu, to pomeni, da je najbližje igrani strukturi. Spet sem bil brez ekipe, snemalec Jovan Jokić je delal tudi ton in luč, jaz pa sem bil sam sebi urednik, režiser in zapisnikar. Ribniška epizoda, čeprav tehnično pomanjkljiva, je kljub vsemu pomembna za celoto, ker je vzpostavila ravnotežje med dvema naracijama, med dvema kulturnima okoljema in med dvema jezikoma.

Del tvojega opusa, ki ga tukaj obravnavava, sega od leta 1975 do 2017. $V$ tem obdobju se je močno spreminjala tehnologija vizualne produkcije. Tvoji prvi omenjeni filmi so posneti na $16 \mathrm{~mm}$ črno beli trak, nato se leta 2006 pojavi prvi video film. Temu sledijo le še filmi, posneti v elektronskem oz. digitalnem mediju. Kako so te spremembe vplivale na tvoje ustvarjanje?

Ni se spremenila samo tehnika, spremenili so se tudi ljudje! Na začetku smo na televiziji sodelovali s snemalci, ki so prišli iz Kino klubov in iz neposredne prakse. Vendar filmarjem televizija ni bila zadosti pomembna in tudi zaslužki so bili manjši. Vsebino so narekovali novinarji in uredniki z radia. To je bila estetika črno-belega kadra oz. ekrana v leseni škatli. V prvem obdobju so imeli pisatelji, gledališki režiserji in igralci na televiziji vodilno besedo.

Nova tehnologija zahteva nove ljudi, predvsem kreativce, tako urednike kot realizatorje - scenariste, režiserje. Srečo sem imel, da sem sodeloval s takimi TV ustvarjalci, kot so moj profesor TV režije Sava Mrmak, meni zelo ljuba Dževad Sabljaković in Aleksandar Spasić. Nove tehnologije so kot nove obleke. Tisti, ki se ravnajo po modi, se začnejo igrati z gumbi in delati trike, ki ne pomenijo prav nič za kakovost televizijske predstave. Po drugi strani pa ti novo orodje lahko pomaga, da se čim bolj približaš vizualni umetnosti, da izboljšaš zvokovno stran, da natančneje predstaviš vsebino in dvigneš naracijo na višjo raven. Že od začetka ukvarjanja s TV režijo sem navajen, da mislim skozi tri, štiri, pet 
... kamer in preko video miksa hkrati montiram in predvajam inscenirano ali naravno prizorišče, da spravim prostor in čas v neko celoto, da postavim sliko pred avditorij.

Moji prvi posnetki iz Slovenije so na $16 \mathrm{~mm}$ filmskem traku. Večina prispevkov za Dvogled in Znanstveni program je v črno-beli tehniki. Danes žalujem za vsakim kosom traku, ki je izpadel v montaži. Nekateri posneti ljudje, kraji in pokrajine so izgubljeni za vedno. Današnja tehnologija omogoča, da ohraniš na trdem disku celotno gradivo, ne glede na količino. To pomeni, da imaš možnost preoblikovati zgodbo, ali pa pustiš neki detajl in ga uporabiš ob drugi priložnosti. Če ne upoštevam koprodukcij z RTS, je gradivo, posneto v produkciji Save, skoraj v celoti ohranjeno. Nič se ne briše, nič se ne zavrže. Tak odnos do posnetih kaset je moj fetiš. Doma hranim skoraj celoten svoj opus, skupaj z nikjer uporabljenimi posnetki. Ta plaz slike in zvoka grozi, da bo pokopal in zmlel ustvarjalca. Tega se zavedam. A še enkrat, vse kar je zabeleženo v sliki in tonu, se lahko prestavi v pisano besedo in postane tiskano čtivo. Uredil sem, da se $v$ dokumentaciji RTS ohrani vse, kar je bilo povedano za oddajo Danilo Kiš, vse spominjanje in vse, kar je bilo rečeno o njegovem ustvarjanju. Imam kompletne posnetke Dušana Makavejeva, od katerih je bila v oddaji uporabljena komaj polovica, drugega je dovolj za novi film ali knjigo. Ta način pristopa ljudem in dogajanjem je potreben, kadar gre za zapise $v$ malih, zaprtih družbah. Tako prispevamo h kulturi spominjanja.

Kako si poiskal producente za filme? Kaj ti je ostalo v spominu na posamezne projekte?

Film »Sita in rešeta« je eden od prvih poskusov realizacije v kombinaciji dveh producentov. Na eni strani je bila RTS, redakcija Izobraževalnega programa, na drugi Društvo Sava. Prvi so sodelovali z ekipo in tehniko doma, v Beogradu, drugi pa s snemanjem v Sloveniji. Z angažiranim snemalcem in Ivanom Debeljakom smo šli $\vee$ Ribnico in posneli hišo Cvarovih, zasebno delavnico suhe robe, Rokodelski center in ravnateljico Polono Rigler Grm. Gotovo se vidi, da je ta del nekoliko slabši v produkcijskem smislu, a vseeno funkcionira na ravni informativnosti in avtentičnosti prizorišča. Konec koncev je najpomembneje, da je bil film predvajan na vseh treh programih RTS in je shranjen $v$ televizijskem arhivu.

Ista redakcija je pomagala realizirati še dva projekta Društva Sava. Eden je »Zlati ključ v mojem srcu«, a drugi »Trije akordi«. Vesna Pavliček se je $v$ okviru serije Predniki in potomci pogovarjala z Mihailom Jurmanom, slovenskim diplomatom, in z Marijo Vauda, likovno umetnico in hčerko skladatelja Zlatana Vaude. Forma oddaj v tej seriji je dokaj omejena. Osnovna dramaturgija temelji na zgodbi glavnega akterja, ki je podprta s fotografsko in filmsko dokumentacijo. $V$ prvem primeru je imel diplomat tri dramaturške vrhunce: zgodbo o preprečevanju 
atentata na Tita na Dunaju, udeležbo na sojenju Adolfu Eichmannu in spremljanje srbskega pisatelja emigranta Miloša Crnjanskega iz Trsta v Jugoslavijo.

Z Jurmanovimi smo stanovali v isti zgradbi na Crvenom Krstu in mi je kot rojaku podaril svojo knjigo »Zlati ključek v mojem srcu«. Bil je pripravljen govoriti. Dobro sta mu šli tako slovenščina kot srbščina, pa sva se uspešno preigrala skozi življenjepis in diplomatsko kariero te dragocene priče in akterja diplomatske zgodovine povojne Jugoslavije.

Celotna televizijska ekipa RTS je realizirala tudi drugo epizodo iz serije Predniki in potomci: »Trije akordi«. Posebnost te oddaje je Marijina neposredna udeležba $v$ vizualizaciji, od post produkcijske obdelave in oblikovanja v grafiki in montaži, do ustvarjanja špice, omota za DVD, zgibanke in plakata. »Trije akordi« so svojevrsten dvojni portret, ker v drugem delu Marija Vauda - pripovedovalka postane Marija - umetnica, izvajalka predstav in promotorka svojega likovnega opusa.

Povej kaj o tem, kako motiviraš protagoniste svojih filmov, da se prepustijo snemanju, in kako si se lotil filma o Davorinu Jenku, ki ne pripoveduje o živi osebi?

Ni vseeno, ali obravnavate živo ali pokojno osebo. V prvem primeru je treba posneti po možnosti vse karakteristične dejavnosti osebe in se z njo dobro spoznati. $V$ drugem primeru se ukvarjate z življenjepisom in dokumenti o delu. $V$ obeh primerih gradite filmsko pripoved, to se pravi dramaturgijo, ki zadošča osnovnim pravilom vizualne umetnosti. Lik je v tem primeru kot božično drevesce, krasite ga z vsem, kar vam je na razpolago.

Najsmelejši projekt, ki je nastal s sodelovanjem Društva Sava,je film za televizijo »Davorin Jenko, skladatelj himen in budnic«. Izkoristil sem obletnico skladateljeve smrti (1914-2014), da bi posnel biografijo avtorja himen: Naprej zastava slave, Bože pravde (srbska) in Tamo onamo (črnogorska). Sodelavka v skoraj vseh mojih filmih, glasbena urednica Ana Pavlović je vključila projekt v redakcijo Šolskega programa RTS. Podprl nas je Muzikološki oddelek Znanstvenega inštituta pri SANU. Lik Davorina Jenka je oživel Jovo Anđić, izkušen moderator in vodnik skozi književno preteklost Beograda. On je hkrati tudi pripovedovalec, povezuje arhivsko gradivo, sogovornike in glasbene priredbe. Obiskali in posneli smo vse važne objekte in kraje, povezane z Jenkovim bivanjem in ustvarjanjem: cerkev v Pančevu, Narodno pozorište v Beogradu, zgradbo Kapetana Miše (nekdaj sedež SANU), Gledališki muzej, Mestno skupščino (bivši Obrenovićev dvor) in sedež Prvega beograjskega pevskega društva. Vsa ta prizorišča so s pomočjo pripovedovalca oživela in pomagala, da se prežamejo z Jenkovo glasbo in duhom časa, v katerem je ustvarjal. Glavni in odgovorni urednik Kulturno umetniškega programa ni dovolil, da bi šli v Jenkov rojstni kraj, zato smo posnetke spo- 
menika Jenku v Cerkljah, spominskega obeležja v Ljubljani, kipa pred Konzervatorijem in groba na Žalah dobili od slovenskih prijateljev.

Na spletni strani Društva Sava sem zasledil nekaj video posnetkov: Miklavževanje in nastop pevskega zbora. Domnevam, da tvoji filmi spodbujajo video dokumentiranje društvenih prireditev. Zdi se mi zelo dobro, da društvo izdeluje video dokumentacijo svojih aktivnosti, da bi se ohranilo pričevanje o njegovem delu. Kaj meniš o tem?

Dejal bi, da je za beleženje bistvenih dogodkov v društvih in manjšinski skupnosti dragocena vsaka pisana, foto in video dokumentacija. Ti zapisi so koristni predvsem pri izdelavi kronik skupnosti in društva, biltenov, publikacij, in ob raznih obletnicah. Obstanek slovenskih kulturnih skupnosti in društev je zasnovan na gojenju običajev, tradicionalnih praznikov in kulturno-umetniških programov, v katerih se zrcali dediščina in pripadnost etnični podobi stare domovine.Zato menim, da je treba usmerjati aktivnost članstva tudi k samostojnemu beleženju, snemanju, fotografiranju vsega, kar je pomembno v dejavnosti društva in skupnosti. Čas je tudi za premišljeno izobraževanje mlajših članov na strokovnih delavnicah za spremljanje dogodkov in proslav z vsemi razpoložljivimi sredstvi. Podobno tistemu, kar si ti dolga leta učil v vaši Poletni šoli vizualne etnografije v Novi Gorici.

V okviru vsake manjšine je vedno v ospredju ohranjanje maternega jezika $v$ družini in $v$ okolju manjšinskih organizacij ter njihovih medijih. $v$ tvojih filmih se to eksplicitno kaže $v$ dvojezičnosti protagonistov. Kakšno je danes stanje manjšinske dvojezičnosti v Srbiji?

Nas, Slovence v Beogradu in širše v Srbiji, močan in usoden vpliv okolja pogosto usmerja k rabi srbskega jezika $v$ medsebojnem občevanju. V glavnem smo se šolali in profesionalno dokazovali v domeni srbskega jezikovnega prostora in kulture. Zahvaljujoč stikom z rodbino $\checkmark$ Sloveniji in potovanjem tja smo ostali na naraven način povezani z jezikom in kulturo prednikov.Zato se tudi v naših filmih govori oba jezika, kot da želimo izražati kompleksnost našega položaja in kulturni ter jezikovni dualizem. Vendar nastaja problem z novo generacijo, rojeno $v$ devetdesetih letih. Takrat je Jugoslavija razpadla, bili smo odrezani od Slovenije in prekinjene so bile vezi z rodnimi kraji in sorodniki. Težko je bilo izražati etnično pripadnost, kaj šele odkrito govoriti slovenski jezik ali se ga učiti. Ta molk je trajal vse do začetka tretjega tisočletja, ko so se Slovenci in njihovi potomci zganili in se začeli organizirati v društva in skupnosti. Srbija je to podpirala in dovolila formiranje slovenske nacionalne manjšine, Slovenija pa je poslala učitelje, da so učili mlade slovenščine.

Dnevi slovenskega filma? Povej, prosim, nekaj o tej zanimivi izkušnji, ki skorajda presega osnovne naloge Društva Sava. 
Revija Dnevi slovenskega filma je nastala iz potrebe, da Slovenci, zbrani v društvih, spoznajo dela slovenskih filmskih ustvarjalcev. Tako so bili filmi prikazovani po raznih dvoranah, brez programskega koncepta in pojasnila. $V$ beograjskem društvu smo nabavili dobro opremo in začeli prikazovati filme $v$ našem novem prostoru. $V$ tem času, od leta 2013 do 2014, sem imel uvodno besedo na TV kanalu, specializiranem za igrane filme o kratkem pregledu slovenskega filma. Te filme sem kasneje prikazal v društvenih prostorih. Nastal je »Kino Sava«! Jugoslovanska kinoteka je sprejela zamisel, da se v novi zgradbi prikaže revija Dnevi slovenskega filma. Na prvi so leta 2015 sodelovali: Maja Weiss, Urška Menart, Martin Turk, Metod Pevec, Jan Cvitkovič, Matjaž Ivanišin in Barbara Zemljarič. Revijo je zaključil »Umetni raj« Karpa Godine in takrat se je začelo tudi sodelovanje Slovenske Kinoteke. Že na prvih Dnevih smo organizirali okroglo mizo »Otroci v vojni« in tribuno »Ženski liki v slovenskem filmu«. Tudi razstave so postale del spremljevalnega programa. Ena od njih je prikazala opus scenografa Dušana Milavca, druga pa filmskega in gledališkega klasika Jožeta Babiča. V letih 2016 in 2017 je sledilo še okoli 20 slovenskih ustvarjalcev in filmskih delavcev, prikazano je bilo 16 dolgometražnih in prav toliko kratkih filmov. Na okroglih mizah smo razglabljali o temah »Vojna v filmu« in »Človekova usoda v jugoslovanskem in post jugoslovanskem filmu«. Ena od tribun je bila posvečena mladim v filmu, druga pa filmski glasbi.

Potekali sta dve delavnici: »(Z)najdi se v prevodu« in »Obdelava zvoka v filmu«. Prvo je vodila dr. Maja Đukanović, ki spodbuja študente s Katedre za slovenski jezik, da prostovoljno prevajajo in podnaslavljajo filme, drugo pa Julij Zornik.

Tako kompleksne prireditve ne bi mogli pripraviti, če v Društvu Sava ne bi imeli sposobnih sodelavcev, med njimi so: Andreja Dimitrijević, profesor montaže na FDU, Dino Dvornik, docent na FDU, Matija Đukanović, montažer, Ivan Zupanc, snemalec in fotograf, Nebojša Rako, dramski umetnik, Sonja Medurić Dinić, strokovnjakinja za marketing, in Tanja Nježić, novinarka.Z nami so še teoretika filma prof. dr. Ivan Kronja in Igor Stanojević ter Miloš Ivanović, producent, ki nas podpirajo kot prijatelji Društva Sava. V okviru Dnevov slovenskega filma je potekalo tudi prvo srečanje filmskih producentov in Filmskih centrov Slovenije in Srbije. Revija se vzporedno prikazuje v Nišu, Pančevu, Vršcu in Novem Sadu. 


\section{Izbrana filmografija Dragomirja Zupanca 1975-2017}

\section{Televizijska produkcija}

\subsection{Serija Dvogled}

Kromberk, Gora nad Ajdovščino, Idrija. 1975. Oddaja Dvogled, Radio televizija Srbija (RTS) - Redakcija programa za otroke, $16 \mathrm{~mm}$ č/b, 29 min. Urednica: Olga Vlatković; voditelj in avtor: Dragan Babić; producent: Gavrilo Azinović; snemalec zvoka: Ratko Kušić; filmski snemalec: Milan Milijanović; izbor glasbe: Dušan Karuović; montažerka: Milada Levi; raziskovalec in režiser: Dragomir Zupanc.

N. Križnar, etnolog in kustos Goriškega muzeja v Novi Gorici, pripoveduje D. Babiću o muzejskih zbirkah in predstavlja eksponate. Paralelno so montirane sekvence, posnete v Kranju s člani skupine OHO: D. Nezom, M. Matanovičem, A. Šalamunom, M. Pogačnikom in N. Križnarjem. Križnar na obisku pri starki na Kovku nad Ajdovščino. Predstavlja tudi izdelovalce jarmov, tkalce in klekljarice na Gori nad Ajdovščino. Babić v Mestnem muzeju Idrija, v zbirki živega srebra. Film se konča z I. Geistrom, ornitologom, med obročkanjem ptic.

Lipica. 1975. Oddaja Dvogled, RTS - Redakcija programa za otroke, $16 \mathrm{~mm}$ č/b, $29 \mathrm{~min}$. Urednica: Olga Vlatković; voditelj in avtor: Dragan Babić; snemalec zvoka: Ratko Kušić; izbor glasbe: Dušan Karuović; filmski snemalec: Milan Milijanović; raziskovalec in režiser: Dragomir Zupanc.

V konjušnici v Lipici D. Babić govori o znamenitih konjih lipicancih in o okolju, v katerem živijo.

Slovenske lipe. 1975. Oddaja Dvogled, RTS - Redakcija programa za otroke, $16 \mathrm{~mm}$, b., $29 \mathrm{~min}$. Urednica: Olga Vlatković; voditelj in avtor: Dragan Babić; snemalec zvoka: Ratko Kušić; filmski snemalec: Milan Milijanović; raziskovalec in režiser: Dragomir Zupanc.

Novinar in pisatelj Miran Satler ter Dragan Babić predstavljata stare slovenske lipe. Zgodbe: Levstikova lipa v Retjah, lipa pri Gradu Turjak, lepota prizorišča v Sorici pri Groharjevi lipi, Polhograjska lipa, aleja lip v Škofji Loki, lipa v Novi Štifti, Prešernova lipa v Ljubljani. Konča se v gostilni Pod lipo, z vročim lipovim čajem.

Nova Gorica, Kobarid, Miren, Šempas. 1975. Oddaja Dvogled, RTS Redakcija programa za otroke, $16 \mathrm{~mm}$, č/b, $29 \mathrm{~min}$. Urednica: Olga Vlatković; avtor in voditelj: Dragan Babić; organizator: Aleksandar Petrović; snemalec zvoka: Ratko Kušić; izbor glasbe: Rade Smiljanić; filmski snemalec: Milan Milijanovič; montažerka: Milica Polićević; raziskovalec in režiser: Dragomir Zupanc. 
Uvod o zgodovini mesta Nova Gorica. Meja med Novo Gorico in Gorico v Italiji. Kobarid, Jože Gruntar pripoveduje o 12. bitki na soški fronti leta 1917 oz. o preboju pri Kobaridu. Spomenik padlim italijanskim vojakom v Kobaridu.

V Mirnu živi in deluje Oskar Kogoj. D. Babić se pogovarja z njim o povezavi med oblikovanjem in naravo. Kogoj demonstrira organsko oblikovane predmete za proizvodnjo v tovarni Ciciban v Mirnu.

V Šempasu živi družina Marka Pogačnika. Ekipa Daljnogleda snema njihovo vsakdanje življenje. Pogačnik pripoveduje o naravi in delu z živalmi in na polju. Z njim so njegove tri hčerke Ajra, Nike in Ana.

Opatje selo, Tolmin, Kovk, Dornberk. 1976. Oddaja Dvogled, RTS - Redakcija programa za otroke, $16 \mathrm{~mm}$, č/b, $29 \mathrm{~min}$. Urednica: Olga Vlatković; avtor in voditelj: Dragan Babić; organizator: Aleksandar Petrović; snemalec zvoka: Ratko Kušić; izbor glasbe: Rade Smiljanić; filmski snemalec: Milan Milijanovič; montažerka: Milica Polićević; raziskovalec in režiser: Dragomir Zupanc.

Bičarska delavnica v Opatjem selu. Babić se pogovarja z izdelovalci. V Tolminski muzejski zbirki v Tolminu sedita N. Križnar in D. Babić. Križnar pripoveduje o etnološki zbirki, podrobnosti o njej pa M. Rutarjeva. Marija Rutar ob kipu Danteja Alighijerija govori o legendi o Dantejevi jami. N. Križnar se pogovarja z Marijo Škvarčevo na Kovku. Na Kovku vidimo tudi klekljarico pri delu. Pekel pri Dornberku v Vipavski dolini. $\mathrm{N}$. Križnar se $v$ starem mlinu pogovarja z lastnico in nekdanjo mlinarico o zgodovini mlina.

Erazmov grad. 1976. Oddaja Dvogled, RTS - Redakcija programa za otroke, 16 mm, č/b, 29 min. Urednica: Olga Vlatković; avtor in voditelj: Dragan Babić; organizator: Aleksandar Petrović; snemalec zvoka: Ratko Kušić; izbor glasbe: Rade Smiljanić; filmski snemalec: Milan Milijanovič; montažerka: Milica Polićević; raziskovalec in režiser: Dragomir Zupanc.

Pod gradom roparskega viteza Erazma Predjamskega v Predjami D. Babić pripoveduje o legendi Erazmovega gradu. D. Babić pripoveduje o Valvazorju in o knjigi Slava vojvodine Kranjske.

Trenta. 1976. Oddaja Dvogled, RTS - Redakcija programa za otroke, $16 \mathrm{~mm}$, č/b, 29 min. Urednica: Olga Vlatković; avtor in voditelj: Dragan Babić; organizator: Aleksandar Petrović; snemalec zvoka: Ratko Kušić; izbor glasbe: Rade Smiljanić; filmski snemalec: Milan Milijanovič; montažerka: Milica Polićević; raziskovalec in režiser: Dragomir Zupanc.

Dolina Soče v Trenti. D. Babić pred Kugyjevim spomenikom. Zgodba o Hemingwayju in gostilni v Tolminu. Znamenita pripoved o divjem lovcu Tožbarju - Špiku iz Trente, ki mu je medved odgriznil spodnjo čeljust. 


\subsection{TV dokumentarci, eseji in portreti}

Ta grdi.1979. RTS - Redakcija znanstvenega programa, 16mm, barvni, 29 min. Odg. urednik Znanstvenega programa: Petar Živadinović; producent: Petar Ivić; organizatorka: Kosovka Ivković; urednik: Ilja Slani; scenarist in voditelj: Naško Križnar; lučkar: Zoran Krsmanović; snemalec zvoka: Dragan Momčilović; izbor glasbe: Vladan Radulović; montažerka: Bojana Subotić; filmska snemalca: Todor Jović, Milovan Urošević; režiser: Dragomir Zupanc.

Naško Križnar, etnolog, kustos Goriškega muzeja v Novi Gorici raziskuje, snema in komentira pustni karneval v Drežnici pri Kobaridu. Na pustno soboto je bil posnet glavni del karnevala - obhod po vasi, od hiše do hiše. V filmu je prikazan prihod sprevoda do hiše, pogovor z gospodarjem in dogajanje $v$ hiši, popoldne pa predstava na vaškem trgu in vedenje posameznih šemskih likov. V prostorih Goriškega muzeja se ob ogledu diapozitivov spomnimo vseh ključnih trenutkov pustovanja in spoznamo njegovo strukturo ter pomen.

Nova umetnost dvajsetih let. 1982. RTS - Redakcija programa za kulturo, 16 mm, barvni, 60 min. Odg. urednica Programa za kulturo: Zora Korać; producent: Đorđe Radmilac; urednica: Dunja Blažević; glasba: Zoran Simjanović; zvok: Jasna Bogojević; montažerka: Milanka Nanović; snemalec: Veselin Krčmar; režiser: Dragomir Zupanc.

Ob priložnosti razstave $v$ Narodnem muzeju $\vee$ Beogradu Zenitizem in konstruktivizem je bila posneta oddaja o umetnikih, ki so ustvarjali v dvajsetih letih 20. stol. Predstavljena so dela Ljubomira Micića, Mihaila Petrova, Jo Kleka, Augusta Černigoja, Eduarda Stepančiča, ob strokovnem vodstvu kustosinje razstave Irine Subotić, kot tudi teoretikov umetnosti Predraga Protića, Petra Krečiče, Aleksandra Flakera, Ješe Denegrija in drugih.

Nova umetnost sedemdesetih let. 1983. RTS - Redakcija Programa za kulturo, 16mm, barvni, 104 min. Odg. urednica: Zora Korać; producent: Đorđe Radmilac; urednica Dunja Blažević; glasba: Zoran Simjanović; zvok: Jasna Bogojević; montažerka: Milanka Nanović; snemalec: Veselin Krčmar; režiser: Dragomir Zupanc.

Pregled umetniške scene $v$ Jugoslaviji v sedemdesetih letih. Predstavljena je skupina umetnikov, zbranih v SKC v Beogradu; izvajalci zagrebške performance skupine; Nuša in Srečo Dragan iz Ljubljane; skupina OHO iz Kranja; Novosadski konceptualni umetniki. O njihovih delih govorijo: Dunja Blažević, Ješa Denegri, Biljana Tomić, Tomaž Brejc, Davor Matičević, Želimir Koščević, Bogdanka Poznanović, Slobodan Tišma. 
Okvir za nekaj slik. 2006. RTS; RTV Slovenija, video BSP, barvni, 60 min. Glavni i odgovorni urednik Kulturno umetniškega programa RTS: Nikola Mirkov. Odgovorna urednica Dokumentarnega programa RTV Slovenija: Živa Emeršič; Producent: Slobodan Radovanović; snemalci zvoka: Uroš Kovačević, Samo Kozlevčar, Slobodan Mišić, Miha Remic; direktor fotografije: Veselin Krčmar; montažer: Goran Mitrović; scenarista: Radmila Radaković in Dragomir Zupanc; režiser: Dragomir Zupanc.

Karpo Godina je prešel vse pomembne etape v ustvarjanju sodobnega jugoslovanskega filma, od amaterske filmske prakse šestdesetih let 20. stol., kjer je uvrščen med pet najboljših amaterjev cineastov na takratni YU lestvici, prek novega vala, kjer se vključuje kot direktor fotografije in montažer, do samostojnih projektov v sedemdesetih in osemdesetih, ko kot celosten avtor (scenarij, režija, kamera, montaža) pomembno prispeva $\mathrm{k}$ filmski estetiki in kinematografski praksi v jugoslovanskem in tudi evropskem kontekstu. O njegovem delu in druženju z njim pripovedujejo številni prijatelji, kolegi, sodelavci, filmski teoretiki in medijski strokovnjaki z različnih območij nekdanje države: Branko Vučićević, Želimir Žilnik, Slobodan Mašić, Filip David, Svetlana Slapšak, Peđa Vranješević, Miša Radivojević, Radoslav Zelenović, Dušan Jovanović, Majda Širca, Vladica Milosavljević, Puriša Đorđević.

Eduard Stepančič. 2006. RTS - Kulturno umetniški program; RTV Slovenija - Dokumentarni program, Beta SP, 29 min. Urednica: Danijela Purešević; producent: Slobodan Radovanović; video snemalca: Veselin Krčmar in Aleš Živec; scenarist in režiser: Dragomir Zupanc.

Portret novo odkritega konstruktivističnega umetnika Eduarda Stepančiča. Sekvence z razstave v Cankarjevem domu. Stepančič govori o sodelovanju z Augustom Černigojem v dvajsetih letih 20. stol.v Trstu. 0 umetniku govorijo Irena Subotić, Ješa Denegri in Peter Krečič.

Zlati ključ v mojem srcu (spomini nekega konzula). 2009. RTS, Redakcija izobraževalnega programa, Beta SP, 29 min. Urednica: Vesna Pavliček; scenarista: Vesna Pavliček, Dragomir Zupanc; snemalec: Đuro Ivanović; režiser: Dragomir Zupanc.

Mihailo Jurman je upokojeni diplomat, pisec spominov Zlatni ključ u mom srcu. Po poreklu je iz Dobove v Sloveniji, po 2. svet. vojni je končal Sindikalno in Obveščevalno šolo. Iz svoje kariere izdvaja epizodo z vrnitvijo srbskega pisatelja Miloša Crnjanskega iz emigracije. Od generalnega konzula v Trstu, Rudija Janhube, je dobil nalogo, da sprejme pisatelja in ga odpelje do ambasadorja Price v Opatijo. Crnjanski je okleval, a ga je Jurman pregovoril in ga prepeljal varno čez mejo.V imenu Jugoslavije je pričal na sodnem procesu proti Eichmannu. Jurman je služboval na Dunaju, ko je bil Tito tam na prvem uradnem obisku. 


\section{Filmi z udeležbo Društva Sava}

SAVA v Beogradu. 2011. Društvo Slovencev v Beogradu - Društvo Sava, Studio Krokar, DCP video, 23 min. Voditeljici projekta: Maja Đukanović in Anica Sabo; sodelujoči: Biljana Milenković-Vuković in Darja Kovrlja; snemalca: Jovan Jekić in Ivan Zupanc; montažer: Nikola Stankić; grafična oblikovalka: Dragana Milovanović-Horvat; prevajalka: Maja Đukanović; tajnica režije: Snežana Goršek; režija: Dragomir Zupanc. Film je nastal s podporo Urada Vlade Republike Slovenije za Slovence $\checkmark$ zamejstvu in po svetu.

Film je bil posnet ob 10. obletnici Društva Slovencev v Beogradu - Društva Sava, ki je bilo ustanovljeno leta 2001. Osnovna dejavnost društva je ohranjanje in promocija slovenskega jezika in kulture v Srbiji. Člani društva so Slovenci in njihovi potomci, živeči v Beogradu.

Film je bil prikazan na mednarodnem festivalu Dnevi etnografskega filma, v Ljubljani leta 2012. Predvajan je bil tudi na proslavi obletnice društva Slovencev v Beogradu, 23. junija 2018.

Ena slovensko-srbska zgodba. 2011. Društvo Sava, Oyster studio, Beograd, OKTV Brežice, Akademski filmski center DKSG Beograd. DCP video, 20 min. Sodelujoči v projektu: Vesna Pavliček, Ljubo Popović, Rut Zlobec; prevajalka: Maja Đukanović; snemalci: Jovan Pavliček, Vladimir Bogovčić; montažer: Jovan Pavliček; scenarist in režiser: Dragomir Zupanc. Film je bil posnet s finančno podporo Urada Vlade Republike Slovenije za Slovence v zamejstvu in po svetu ter Sekretariata za kulturo mesta Beograd.

Ana Pečnik, mlada profesorica biologije iz Maribora je prišla leta 1941 v Smederevsko Palanko in začela poučevati na gimnaziji. Po osvoboditvi se je poročila z Borom Simićem in postala gospa Mirjana Simić. V filmu govori o svojem življenju med Slovenijo in Srbijo, med Bistrico ob Sotli in okolico hrama Svetog Save v Beogradu.

Film je bil predvajan na festivalu Dokumentarnega in kratkega igranega filma v Domu Omladine, Beograd, leta 2012, istega leta tudi v občini Vračar v Beogradu in v Društvu Sava. Premiero na RTS je doživel leta 2013.

Sita in rešeta mojstra Debeljaka. 2012. Rokodelski center Ribnica, Društvo Slovencev v Beogradu - Društvo Sava, RTS. DCP video, 42 min. Producenta: Polona Rigler Grm (Rokodelski center Ribnica) in Zoran Jovanović (Izobraževalni program RTS); urednica: Vesna Pavliček; scenarista: Polona Rigler Grm in Dragomir Zupanc; video snemalec: Jovan Jekić; snemalec tona: Milan Đorđević; fotograf: Ivan Zupanc; grafik: Dragana Horvat Milovanović; izbor glasbe: Ana Pavlović; montažer: Nikola Stankić; režiser: Dragomir Zupanc. Film je bil posnet $s$ finančno podporo Urada Vlade Republike Slovenije za Slovence v zamejstvu in 
po svetu, Ministrstva za izobraževanje, znanost, kulturo in šport Republike Slovenije, Občine Ribnica in Nacionalnega sveta slovenske manjšine $v$ Srbiji.

Edo Cvar iz Slatnika pri Ribnici je kmalu po koncu prve svetovne vojne v Beogradu ustanovil sitarsko delavnico. Hiša v Gružanski ulici je še danes središče za proizvodnjo in distribucijo suhe robe v Srbiji. Naslednik mojstra Cvara, Ivan Debeljak, nadaljuje z obdelavo in popravili sit $v$ delavnici, v kateri je kot mojster delal že njegov oče. Še vedno je $\checkmark$ stiku z mojstri in proizvajalci suhe robe v Ribniški dolini v Sloveniji. Ivan je tudi glasbenik in član Društva Sava, kjer se družijo Slovenci, živeči v Beogradu, in njihovi potomci.

Film je doživel premiero v občini Vračar v Beogradu leta 2012. Predvajan je bil na Dnevih etnografskega filma v Ljubljani leta 2013. Predvajan in nagrajen je bil na reviji duhovnega filma Bdenje duša, Sremski Karlovci, 2013 in 2015. Večkrat je bil predvajan tudi na Drugem in Tretjem programu RTS.

Trije akordi. Serija: Predniki in potomci. 2014. RTS - Kulturno izobraževalni program, DCP video, 29 min. Odgovorni urednik Uredništva za znanost in izobraževanje: Ilija Cerović; urednica: Vesna Pavliček; glasbena urednica: Ana Pavlović; snemalec zvoka: Ljuba Jovanović; direktor fotografije: Nebojša Đorđević; montažer: Vladan Radovanović; oblikovalka: Marija Vauda; prevajalka: Maja Đukanović; scenarist in režiser: Dragomir Zupanc. Film je nastal v sodelovanju z Ministrstvom za kulturo in informiranje Republike Srbije ter Društvom Slovencev v Beogradu - Društvom Sava.

Družina Vauda je prispela v Srbijo leta 1941, v času prisilnega izseljevanja Slovencev s Štajerske. Zgodba o dirigentu in skladatelju Zlatanu Vaudi se začne $v$ Kragujevcu. Vzgojen $v$ družini učiteljev je še kot otrok nastopal v domačem orkestru in pel $v$ šolskem zboru. Diplomiral je iz kompozicije pri Marku Tajčeviću na Fakulteti za glasbeno umetnost $v$ Beogradu in kariero pričel kot dirigent. Skladal je za Otroški zbor Radia Beograd, katerega dirigent je bil. Poleg skladb za manjše glasbene ansamble, vokale in orkestre je zložil tudi prvo otroško opero, Ježkovo hišico. O ustvarjanju in umetniškem opusu Zlatana Vaude govori njegova hči Marija Vauda. Odraščanje ob očetu je vplivalo na njeno ustvarjalnost na področju slikarstva. $V$ filmu vidimo posnetke njenih razstav in performansov. Soustvarila je tudi vizualno podobo tega filma. Predvajan je bil na reviji duhovnega filma Bdenje duša, Sremski Karlovci, 2014.

Davorin Jenko - ustvarjalec himen in budnic. 2014. RTS - Kulturno izobraževalni program, Muzikološki inštitut Srbske akademije znanosti in umetnosti (SANU), Nacionalni svet Slovenske nacionalne manjšine v Republiki Srbiji, Društvo Slovencev v Beogradu - Društvo Sava, DCP 
video, 65 min. Urednica: Ana Pavlović; voditelj: Jovan Anđić; prevajalka v slovenščino: Maja Đukanović; direktor fotografije: Milan Stanić; grafika: Valentina Danilović; oblikovalka: Marija Vauda; glasbeni urednik: Ana Pavlović; montažer: Đorđe Anđelković; scenarista Ana Pavlovič in Dragomir Zupanc; režiser: Dragomir Zupanc.

Slovensko-srbski skladatelj in glasbenik Davorin Jenko, doma iz Dvorij pri Cerkljah na Gorenjskem, je z budnico Naprej zastava slave in $z$ drugimi rodoljubnimi pesmimi pomembno vplival na mlade panslaviste, zbrane $v$ društvih in zborih $v$ šestdesetih letih 19. stoletja. Umetniški vrhunec in zrelost je dosegel v kneževini, kasneje kraljevini Srbiji, kot zborovodja in kapelnik Narodnega gledališča v Beogradu. K srbski glasbeni kulturi je prispeval številne skladbe za odrske izvedbe, uverture in popularne pesmi. Uglasbil je tudi aktualno srbsko himno Bože pravde.

Film je bil predvajan ob obletnici skladateljeve smrti v dvorani SANU, kot osrednji dogodek na Akademiji v čast Davorina Jenka leta 2014. Predvajan in nagrajen je bil na reviji duhovnega filma Bdenje duša, Sremski Karlovci, 2015. Večkrat je bil predvajan na Drugem in Tretjem programu RTS.

Življenje in spomin. 2017. Društvo Slovencev v Beogradu - Društvo Sava in Platforma, DCP video, 25 min. Producenta: Saša Verbič in Miloš Ivanović; direktor fotografije in snemalec zvoka: Dušan Krivec; montažer: Matija Đukanović; oblikovalec zvoka: Dino Dolničar; prevajalka: Maja Đukanović; scenarist in režiser: Dragomir Zupanc. Film je bil izdelan s pomočjo Nacionalnega sveta slovenske nacionalne manjšine $v$ Republiki Srbiji.

Zakonca Nuša in Rene Gerden sta se iz Slovenije preselila na Dorćol, v beograjsko občino, v zgodnjih petdesetih letih 20. stol. Rene je projektiral hišo v ulici Strahinjić Bana, namenjeno inženirjem in arhitektom, združenim v stanovanjsko zadrugo. Petčlanska družina je bila aktivna tako $v$ beograjskem mestnem okolju kot tudi $v$ idiličnem Trebnjem v Sloveniji, od koder izvira Nušina družina in kjer sta se zakonca spoznala. Pokojni Rene je pustil za seboj več zvezkov družinske kronike, ilustrirane z njegovimi risbami, kolaži in beležkami o dogodkih v družini Gerden. Nuša je najstarejša članica Društva Slovencev v Beogradu - Društva Sava in ustanoviteljica ženskega pevskega zbora Pojoča družba. Še v svojih poznih osemdesetih letih je izredno aktivna in prisotna na vseh dogodkih ter praznovanjih v Društvu Sava.

Film je bil premierno predvajan na Drugem programu RTS 7. februarja, 2018. Film je sodeloval na Euro info festivalu 2018, na več kot 15 mestih v Srbiji. Na Jahorina film festu je leta 2018 prejel Zlati javor za prispevek kinematografiji. 


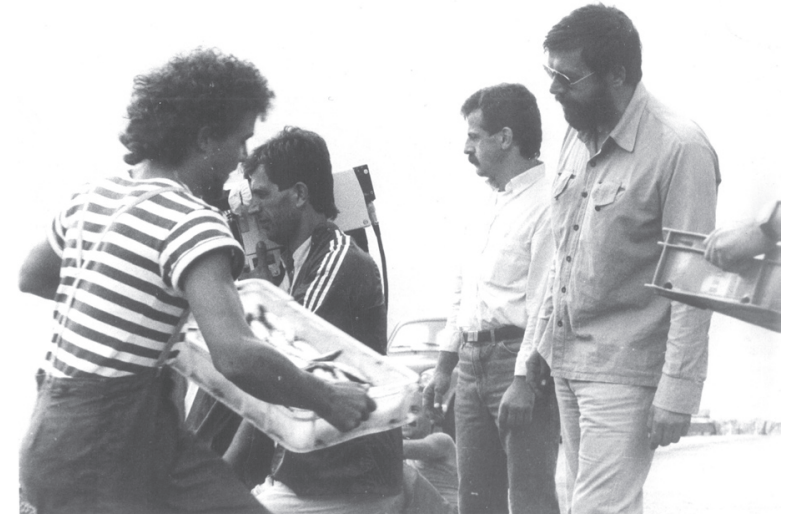

Zupanc z ekipo v času službovanja na RT Črna Gora (1985-1990)

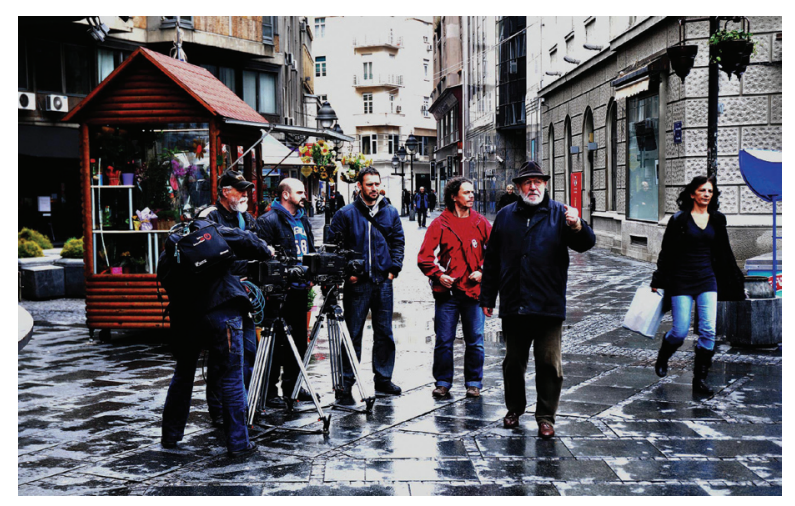

Zupanc z ekipo RTS v Beogradu

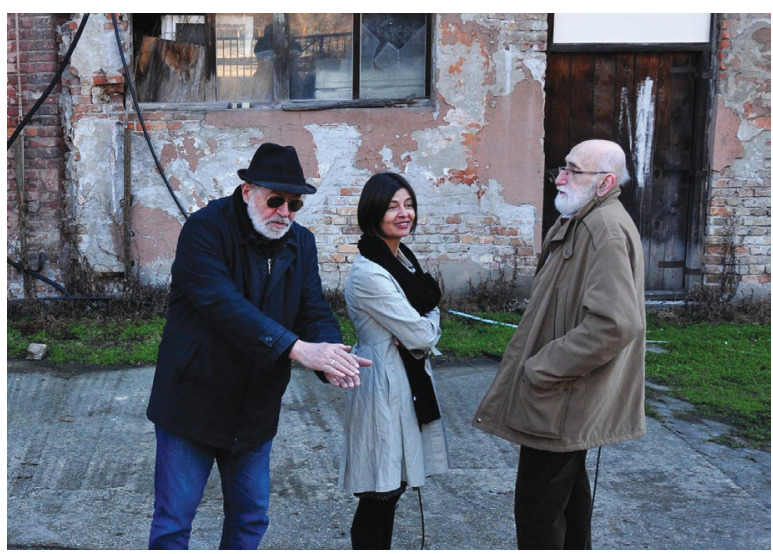

Zupanc med snemanjem filma o Branku Vučićeviću (2006) 


\section{N. Križnar}

Filmski mostovi Dragomirja Zupanca...

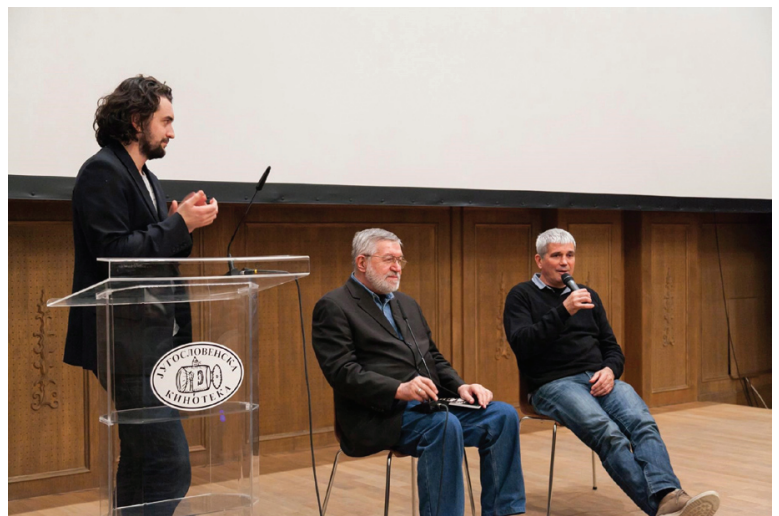

Razgovor po filmu Metoda Pevca na Dnevih slovenskega filma (2015)

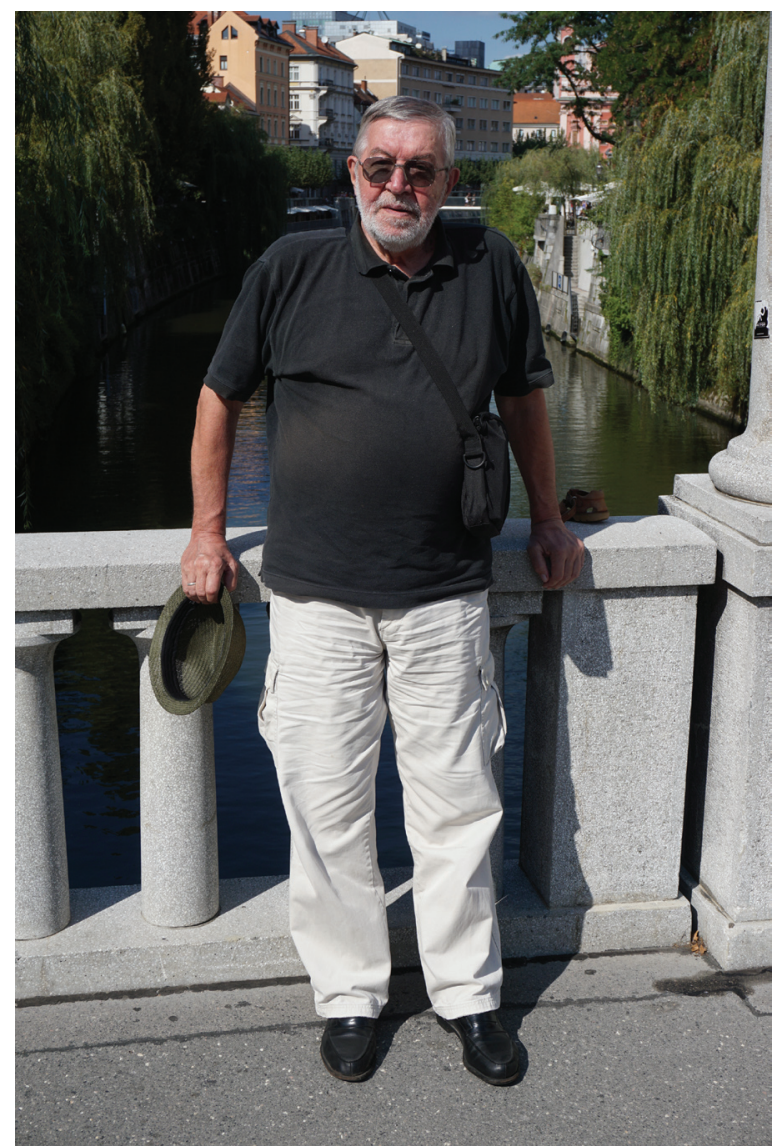

Dragomir Zupanc na Šuštarskem mostu v Ljubljani v času razgovora o njegovih filmih, Ljubljana, sept. 2018. Foto Naško Križnar 